\title{
ANALISIS SUHU, pH DAN KUANTITAS KOMPOS HASIL PENGOMPOSAN REAKTOR AEROB TERMODIFIKASI DARI SAMPAH SISA MAKANAN DAN SAMPAH BUAH
}

\author{
Sri Wahyuni Siagian'), Yebi Yuriandala' ${ }^{1)}$, Fina Binazir Maziya1) \\ ${ }^{1)}$ Program Studi Teknik Lingkungan, Universitas Islam Indonesia, Yogyakarta \\ Email: yebi.y@uii.ac.id
}

\begin{abstract}
Abstrak
Komposisi sampah di Daerah Istimewa Yogyakarta didominasi oleh sampah organik yang berasal dari sampah sisa makanan dan sampah buah. Komposisi sampah sisa makanan ini merupakan komposisi terbesar penyumbang timbulan sampah yaitu sebesar 57,08\%. Sedangkan komposisi sampah buah di salah satu pasar tradisional mencapai $44 \%$ dari sampah organik lainnya. Untuk mengurangi timbulan tersebut dapat dilakukan pengomposan dengan metode yang efektif dan efisien. Penelitian ini mengkombinasikan sampah sisa makanan dan sampah buah sebagai bahan baku pengomposan. Tujuan penelitian untuk mengetahui parameter yang mempengaruhi pengomposan dan kuantitas kompos dengan metode reaktor aerob termodifikasi. Penelitian dilakukan selama 30 hari menggunakan dua buah reaktor dengan massa awal feedstock $8 \mathrm{~kg}$ pada masing-masing reaktor. Suhu akhir yang diperoleh pada reaktor ldiperoleh sebesar $28^{\circ} \mathrm{C}$ dan $27^{\circ} \mathrm{C}$ pada reaktor 2 . Pada reaktor 1 dan 2 suhu kompos sudah mencapai suhu tanah. pH kedua reaktor masih masuk dalam rentang kriteria standar SNI karena pada akhir pengomposan, pH kedua reaktor pada penelitian ini mendekati netral yaitu berkisar 7-7,4. Massa kompos akhir pada reaktor satu sebesar 1,800 $\mathrm{kg}$ dan 0,740 kg untuk reaktor dua.
\end{abstract}

Kata kunci: Kompos, pH, Reaktor, Suhu

\begin{abstract}
Waste composition in Special Region of Yogyakarta is dominated by organic waste come from food waste and fruit waste. The composition of the residual food waste was the composition of the largest contributor to a solid waste generation that is equal to 57,08\% at Yogyakarta Province. While the composition of fruit waste in one of the traditional market is $44 \%$ of the other organic waste. Composting using an effective and efficient method can reduce the composition of the waste. This research combines food waste and fruit waste as raw material for composting. This study aimed to know the parameters that affect the composting process and the quantity of compost by the method of modified aerobic reaktor. The study was conducted over 30 days using two reaktors with initial mass feedstock $8 \mathrm{~kg}$ in each reaktor. The final temperatue obtained were $28^{\circ} \mathrm{C}$ in reaktor 1 and $27^{\circ} \mathrm{C}$ in reaktor 2. The $p H$ of the two reaktors is still in the range of the SNI because at the end of composting, the $p H$ of the two reaktors was nearly neutral, ranging from 7-7,4. The quantity of solid compost obtained were $1,800 \mathrm{~kg}$ in recator 1 and $0.740 \mathrm{~kg}$ in reaktor 2.
\end{abstract}

Keywords : Compost, pH, Reactor, Temperature

\section{PENDAHULUAN}

Peningkatan volume sampah tidak terlepas dari pertambahan jumlah penduduk dan perubahan pola konsumsi masyarakat. Semakin maju gaya hidup manusia, semakin banyak sampah yang dihasilkan. Di Indonesia salah satu jenis sampah yang memiliki komposisi besar didominasi oleh sampah organik yang berasal dari sisa makanan. Kementerian Lingkungan Hidup dan Kehutanan (2017) menyatakan bahwa jenis sampah organik di Indonesia memiliki persentase terbesar, yaitu sebesar $60 \%$. 
Masalah yang sama juga terjadi pada daerah yang sedang berkembang salah satunya Daerah Istimewa Yogyakarta . Menurut Sistem Informasi Pengelolaan Sampah Nasional tahun 2020 menunjukkan komposisi sampah yang paling banyak di DIY adalah sisa makanan sebesar $57,08 \%$. Selain sampah sisa makanan, sampah buah juga harus menjadi perhatian khusus sebab sampah buah juga merupakan sampah yang dihasilkan oleh rumah tangga serta beberapa jenis buah-buahan ada yang tidak mengenal musim, dimana sepanjang tahun selalu ada sehingga akan menimbulkan penumpukan yang cukup besar. Sampah buah juga memiliki timbulan yang cukup besar khususnya di pasar-pasar tradisional dan pedagang buah di salah satu kabupaten di DIY yaitu Kabupaten Sleman, dimana komposisi sampah buah disalah satu pasar tradisional di Kabupaten Sleman mencapai $44 \%$ dari sampah organik lainnya (Iswadianto, 2018). Biasanya para pedagang membiarkan sampah buah yang sudah membusuk sehingga menumpuk dan menimbulkan bau yang tidak sedap.

Salah satu cara memanfaatkan kembali sampah sisa makanan dan sampah buah serta untuk meminimalisasi sampah yang menumpuk di Tempat Pemrosesan Akhir (TPA) yaitu dengan memanfaatkan sampah tersebut menjadi kompos. Kompos adalah bentuk akhir dari bahanbahan organik sampah domestik setelah mengalami dekomposisi. Pengolahan sampah menjadi kompos juga memberikan nilai ekonomi yang lebih apabila standar kualitas kompos yang dihasilkan baik (Rahardyan, 2006).

Pada penelitian sebelumnya bertujuan untuk menemukan teknologi tepat guna pengolahan sampah organik yang dititik beratkan pada pemanfaatan penguraian sampah organik oleh larvalarva serangga menggunakan reaktor sederhana. Banyaknya potensi sampah yang ada serta belum adanya penelitian yang lebih lanjut maka penelitian ini dilakukan untuk mengetahui parameter yang mempengaruhi pengomposan dan kuantitas kompos menggunakan sampah sisa makanan dan sampah buah dengan reaktor aerob termodifikasi guna menemukan metode pengomposan yang lebih efektif dan efisien yang tidak memakan banyak lahan serta menghasilkan hasil samping yang memiliki nilai ekonomis.

\section{METODE PENELITIAN}

\subsection{Persiapan Penelitian}

Reaktor dibuat 4 ruang dengan memberi sekat untuk membatasi masing-masing ruangnya (Gambar 1). Ruang paling atas digunakan sebagai tempat menggantungkan keranjang sampah untuk feedstock yang dikomposkan dengan massa sampah total $8 \mathrm{~kg}$ per reaktor. Ruang kedua dari atas merupakan ruang kosong karena digunakan untuk resirkulasi udara dengan volume 
$0,0125 \mathrm{~m}^{3}$. Ruang ketiga untuk penampungan maggot dengan volume ruang $0,05 \mathrm{~m}^{3}$ dan ruang paling bawah digunakan untuk pupuk cair sebesar $0,0625 \mathrm{~m}^{3}$ dengan menaruh ember pada ruang tersebut.

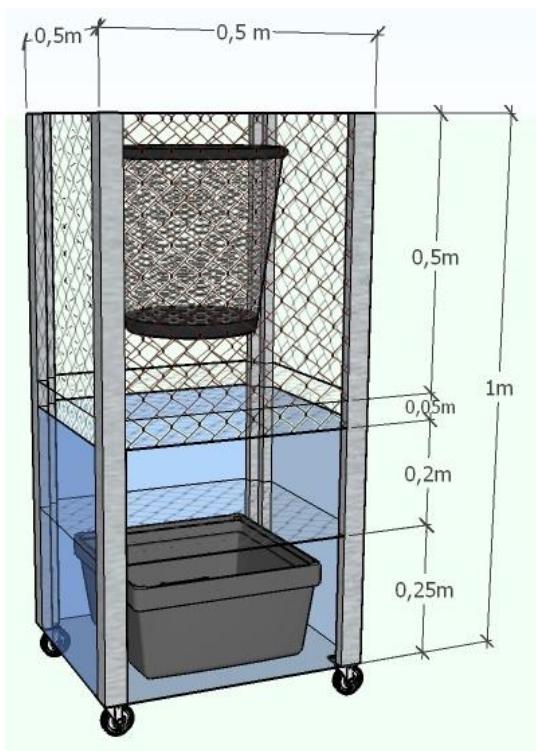

Gambar 1. Reaktor yang digunakan pada proses pengomposan

Parameter yang dipantau adalah suhu dan $\mathrm{pH}$ serta kuantitas hasil pengomposan yang dihitung adalah massa kompos. Pada persiapan penelitian dilakukan dua tahapan, yakni persiapan alat dan bahan serta persiapan pembuatan kompos. Alat dan bahan yang digunakan dalam pembuatan reaktor yaitu :

a. Alat : gunting, cutter, meteran, gerinda, spidol dan soldier

b. Bahan : Besi siku, siku segitiga, baut, waring anyaman, jarring, fiberplat, ember, roda hidup, kabel ties, keranjang sampah dan tali tambang

\subsection{Pengomposan}

Proses pengomposan yang dilakukan pada penelitian ini adalah pengomposan secara aerob karena reaktor hanya dibuat dengan menggunakan jaring-jaring sehingga udara dapat keluar masuk dengan bebas. Sampah yang digunakan pada reaktor 1 berupa $2 \mathrm{~kg}$ sampah sisa makanan dan $6 \mathrm{~kg}$ sampah buah atau memiliki perbandingan 1:3. Sedangkan pada reaktor 2 menggunakan $6 \mathrm{~kg}$ sampah sisa makanan dan $2 \mathrm{~kg}$ sampah buah atau memiliki perbandingan 3:1. Langkah pertama dalam pembuatan kompos adalah dengan mencampur sampah sisa makanan dan sampah buah yang telah dicacah atau dipotong kecil-kecil. Sampah buah yang digunakan perlu dicacah terlebih dahulu karena didominasi oleh buah-buahan seperti belimbing, apel, jeruk, alpukat, mangga, jambu, kiwi, pisang, anggur dan beberapa buah semangka. Kemudian sampah 
dicampur dan diaduk kedalam ember sehingga merata. Setelah sampah merata, campuran kemudian dimasukkan kedalam reaktor.

Parameter yang diukur selama 30 hari proses pengomposan yaitu suhu dan $\mathrm{pH}$. Pengukuran suhu selama proses pengomposan dilakukan dengan menggunakan termometer. Pengukuran suhu ini dilakukan setiap hari dalam tumpukan kompos yang didiamkan selama 2-3 menit. Sedangkan pengukuran $\mathrm{pH}$ dilakukan setiap hari menggunakan $\mathrm{pH}$-moisture meter. Data yang diperoleh pada penelitian ini meliputi data suhu dan $\mathrm{pH}$ kemudian melakukan analisis komparasi dengan membandingkan hasil uji tersebut menggunakan SNI 19-7030-2004. Sedangkan kuantitas hasil pengomposan yang dihitung adalah massa kompos. Pengukuran massa kompos padat dilakukan setiap hari menggunakan portable electronic scale.

\section{HASIL DAN PEMBAHASAN}

\subsection{Kondisi Sampah}

Sampah organik yang digunakan pada penelitian ini adalah sampah sisa makanan dan sampah buah yang telah dicacah secara manual. Sampah dimasukkan kedalam dua reaktor dengan massa $8 \mathrm{~kg}$ pada masing-masing reaktor. Sampah sisa makanan dan sampah buah yang digunakan bervariasi serta dari sumber yang berbeda-beda. Sampah sisa makanan didominasi oleh nasi, nasi dengan campuran kuah sehingga lebih berlemak, sisa tulang-tulangan dan beberapa ada yang bercampur dengan sayur. Sedangkan sampah buah didominasi oleh buahbuahan berupa belimbing, apel, jeruk, alpukat, mangga, jambu, kiwi, pisang, anggur dan beberapa buah semangka.

\subsection{Proses Pengomposan}

Berjalannya proses pengomposan dipengaruhi oleh beberapa faktor seperti suhu, dan $\mathrm{pH}$. Pengukuran faktor-faktor tersebut sebagai unsur pendukung tiap variasi selama proses pengomposan. Hasil penelitian terkait suhu dan $\mathrm{pH}$ akan dibahas lebih lanjut, sebagai berikut :

\section{a. Nilai suhu selama 30 hari proses pengomposan}

Suhu berperan penting dalam memberikan informasi tentang aktivitas mikroorganisme yang ada saat proses pengomposan. Pengukuran suhu dilakukan setiap hari menggunakan thermometer dengan satuan derajat Celcius $\left({ }^{\circ} \mathrm{C}\right)$. Suhu menandakan perubahan aktivitas mikroorganisme dalam menguraikan bahan organik. Data suhu kompos yang didapatkan selama pengomposan juga dapat menggambarkan tahapan pengomposan. 
Perubahan suhu pada kedua reaktor terlihat sangat berbeda seperti yang dapat dilihat pada Gambar 2. Pada reaktor satu dengan komposisi sampah $2 \mathrm{~kg}$ sisa makanan $+6 \mathrm{~kg}$ buah suhu maksimum mencapai $34^{\circ} \mathrm{C}$ dihari pertama dan pada reaktor dua dengan komposisi sampah 6 $\mathrm{kg}$ sisa makanan $+2 \mathrm{~kg}$ buah suhu maksimum mencapai $39^{\circ} \mathrm{C}$ pada hari ke-20. Pada reaktor satu suhu hari ke 0-8 terlihat fluktuatif, hal tersebut merupakan tahap dimana mikroba yang terdapat dalam bahan baku kompos beradaptasi atau mulai berkembangbiak. Kemudian pada hari ke 8-30 suhu menunjukan relatif stasioner yaitu berkisar antara $27^{\circ} \mathrm{C}-30^{\circ} \mathrm{C}$. Sedangkan pada reaktor dua dari hari ke-21 suhu menurun secara bertahap. Penurunan tersebut disebabkan oleh aktivitas mikroba menurun dalam menguraikan kadar bahan organik yag tersedia serta menunjukkan bahwa kompos telah memasuki fase kematangan. Menurut Dewilda (2017), kompos dinyatakan matang jika sudah mencapai suhu air tanah yaitu $\leq 30^{\circ} \mathrm{C}$. Menurut Sriharti dan Salim (2010), kompos dikatakan matang apabila suhu kompos telah sama dengan suhu air $\operatorname{tanah}\left(28^{\circ} \mathrm{C}-30^{\circ} \mathrm{C}\right)$.

Suhu yang lebih dari $40^{\circ} \mathrm{C}$ diindikasikan sebagai fase termofilik, yaitu fase dimana terjadi proses dekomposisi yang sangat aktif oleh mikroba. Pada reaktor satu dan dua tidak terlihat suhu lebih dari $40^{\circ} \mathrm{C}$. Suhu fluktuatif yang terjadi selama pengomposan dapat dipengaruhi oleh perbedaan suhu pada lingkungan selama penelitian berlangsung. Kondisi cuaca yang terjadi selama pengomposan juga berdampak pada suhu kompos.

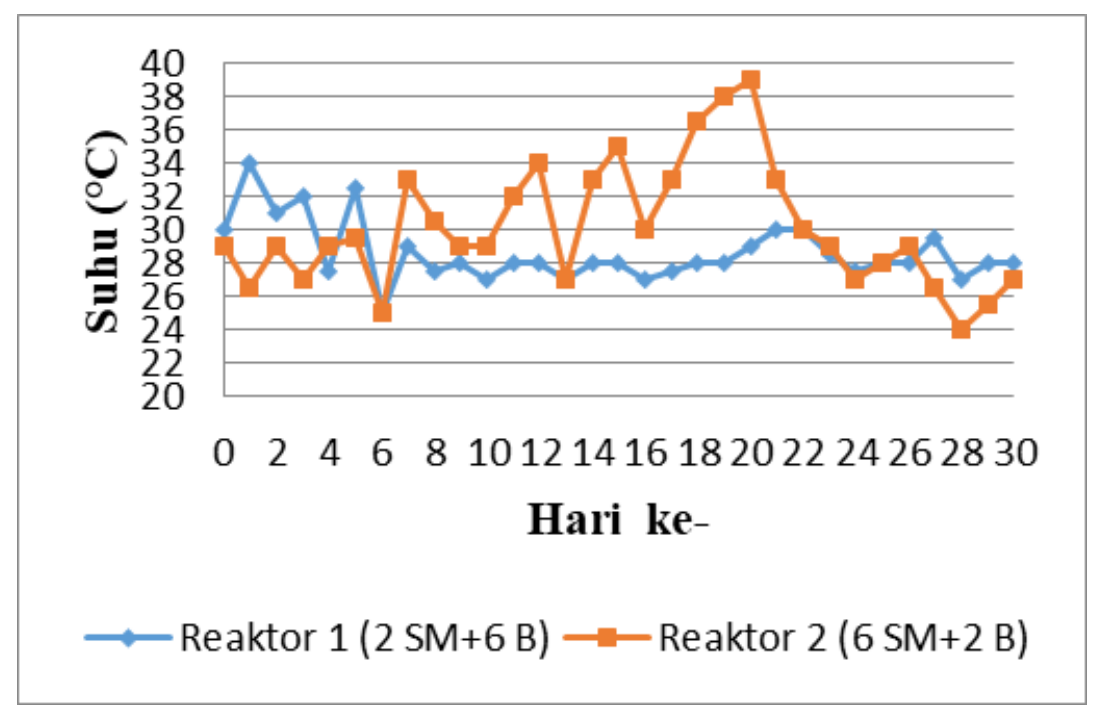

Gambar 2. Perubahan nilai suhu selama 30 hari proses pengomposan 


\section{b. Nilai pH}

Pengukuran $\mathrm{pH}$ dilakukan setiap hari menggunakan $\mathrm{pH}$-moisture meter dengan hasil seperti yang dapat dilihat pada Gambar 3. $\mathrm{pH}$ berpengaruh terhadap mikroorganisme dalam mendekomposisi bahan organik. Gambar 3 menunjukkan hasil pengukuran nilai pH. Pada awal pengomposan $\mathrm{pH}$ berada dikisaran antara 5,5 - 7. Hal ini menunjukkan bahwa mayoritas yang mendegradasi sampah adalah jamur karena pada penelitian yang pernah dilakukan Rentang optimum pH untuk bakteri adalah 6 - 7,5, sedangkan untuk Jamur berkisar antara 5,5 - 8 dan untuk pH pada kotoran ternak optimum pada pH 6,8 - 7,4 (Anindita, 2012). Pada tahap akhir proses pengomposan $\mathrm{pH}$ akan menjadi 6,78 - 7,81 (Liu, et al, 2019). pH yang cenderung asam justru menguntungkan karena dapat menghasilkan unsur nitrogen yang sangat banyak dan mematikan nimfa atau telur dari serangga atau organisme pathogen lainnya (Setyaningsih et al., 2017).

Pada penelitian yang dilakukan menunjukkan awal pengomposan terdapat jamur berwarna putih pada kedua reaktor. Kemudian $\mathrm{pH}$ akan mengalami peningkatan seiring berjalannya proses dekomposisi oleh senyawa organik. Pada reaktor $1 \mathrm{pH}$ mengalami peningkatan pada hari ke-18 yang disebabkan oleh aktivitas mikroorganisme dalam pemecahan nitrogen organik menjadi amonia. Amonia meningkatkan pH karena sifatnya yang basa.

Menurut Dewilda (2017), kenaikan pH yang terjadi karena pada proses pengomposan akan dihasilkan amonia dan gas nitrogen sehingga nilai $\mathrm{pH}$ berubah menjadi basa karena aktivitas bakteri yang meningkat. Sehingga mendekati akhir pengomposan, $\mathrm{pH}$ reaktor 1 mendekati netral yaitu berkisar 7-7,4. Sedangkan pada reaktor 2 dihari ke-16 hingga hari 19 nilai $\mathrm{pH}$ berkisar 4-5 atau mengalami penurunan, hal tersebut karena dengan aktivitas mikroorganisme didalam sampah maka temperatur akan mulai naik dan akhirnya menghasilkan asam organik yang mengakibatkan nilai $\mathrm{pH}$ menurun. Jika dihubungkan dengan suhu, suhu pada reaktor 2 dihari ke-16 hingga hari 19 mengalami kenaikan berkisar $30-38^{\circ} \mathrm{C}$. Kemudian pada hari ke-20 hingga 30 nilai $\mathrm{pH}$ reaktor 2 mendekati netral yaitu berkisar 7-7,4. Hal tersebut merupakan proses dimana mikroorganisme dari jenis lain akan mengkonversikan asam organik yang telah terbentuk sehingga sampah memiliki derajat keasaman yang tinggi dan mendekati netral (Djuarnani, et al., 2005). 


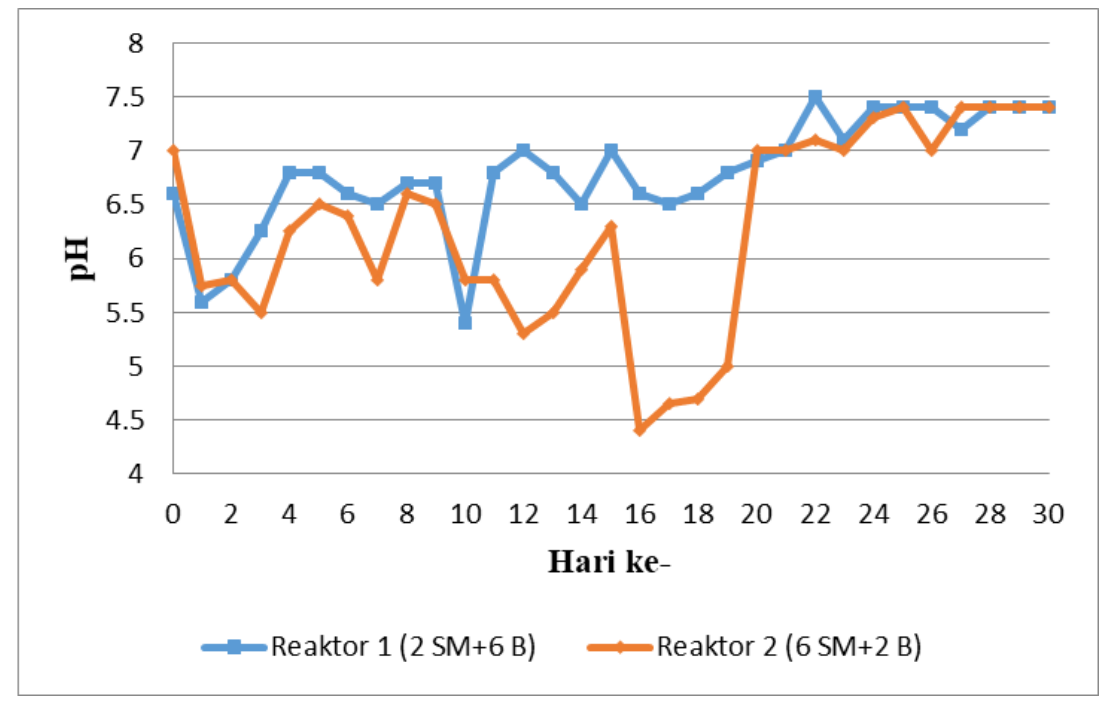

Gambar 3. Perubahan nilai pH selama 30 hari proses pengomposan

\subsection{Kuantitas Kompos padat}

Pengukuran massa kompos padat dilakukan setiap hari menggunakan portable electronic scale dengan hasil seperti yang ditunjukkan oleh Gambar 4.. Massa awal kompos yang digunakan sebanyak $8 \mathrm{~kg}$ dengan komposisi $2 \mathrm{~kg}$ sampah sisa makanan dan $6 \mathrm{~kg}$ sampah buah pada reaktor satu. Sedangkan pada reaktor dua memiliki komposisi $6 \mathrm{~kg}$ sampah sisa makanan dan $2 \mathrm{~kg}$ sampah buah. Pengukuran massa kompos padat guna mengetahui penurunan massa dari awal pengomposan hingga akhir dari proses pengomposan yang dilakukan selama 30 hari. Berikut adalah hasil pengukuran massa kompos selama 30 hari proses pengomposan:

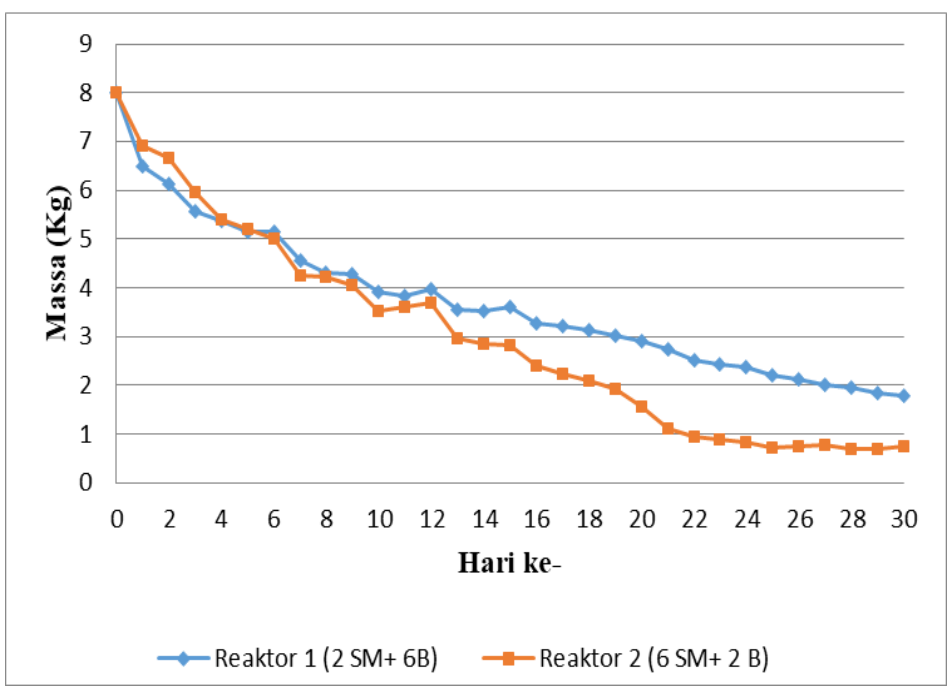

Gambar 4. Penurunan massa kompos padat pada masing-masing reaktor selama proses pengomposan 
Berdasarkan hasil pengukuran perubahan massa pada kedua reaktor menunjukkan terjadi penurunan setiap harinya. Pengukuran massa dilakukan pengulangan sebanyak tiga kali agar mendapat tingkat akurasi yang lebih tinggi. Massa kompos akhir pada reaktor satu sebesar 1,800 $\mathrm{kg}$ dan $0,740 \mathrm{~kg}$ untuk reaktor dua. Massa kompos berkurang sampai setengahnya dan tumpukan bahan menyusut dikarenakan proses perombakan bahan organik menghasilkan panas yang menguapkan air dan $\mathrm{CO}_{2}$ dalam pengolahan bahan organik. Massa sampah dapat menyusut drastis akibat terjadinya penurunan kadar air pada sampah yang sedang dikomposkan dan berubah menjadi kompos cair. Hadisuwito (2007) menyatakan bahwa komposter memungkinkan untuk mengalirkan air lindi, sehingga kadar air dan bahan padat terpisah dan menjadi kompos cair.

Selain itu, maggot yang ada pada proses pengomposan juga menyebabkan penurunan massa karena sampah terdegradasi oleh bantuan maggot. Menurut Yu et al. (2011) maggot memiliki bakteri dalam pencernaannya yang mampu menguraikan sampah organik. Maggot yang dihasilkan selama proses pengomposan digolongkan menjadi dua jenis yaitu maggot Black Soildier Fly $(B S F)$ dan maggot non BSF serta tidak ada penambahan bibit maggot selama proses pengomposan. Maggot BSF dengan ciri-ciri maggot lebih panjang dan kurus serta memiliki warna lebih coklat bila dibandingkan dengan maggot lainnya. Semakin banyak maggot yang keluar maka semakin banyak sampah yang terdegradasi oleh maggot tersebut.

Penurunan massa reaktor dua lebih drastis dibandingkan dengan reaktor satu, ditunjukkan dengan massa akhir pada reaktor satu sebesar $1,800 \mathrm{~kg}$ dan $0,740 \mathrm{~kg}$ untuk reaktor dua yang mulanya $8 \mathrm{~kg}$. Salah satu hal yang mempengaruhi penurunan tersebut adalah pada reaktor dua produksi maggot BSF yang dihasilkan lebih banyak pada reaktor satu. Mulai dari hari ke-21 hingga hari 30 maggot BSF yang dihasilkan pada reaktor satu memiliki rata-rata $0,614 \mathrm{~kg}$ sedangkan 5,271 kg pada reaktor dua. Hal tersebut menunjukkan bahwa sampah pada reaktor dua lebih banyak terdegradasi oleh bantuan maggot BSF yang menyebabkan penurunan massa kompos padatnya lebih drastis.

Beberapa penelitian juga menunjukkan larva BSF mampu mendegradasi sampah organik, baik dari hewan maupun tumbuhan lebih baik dibanding serangga lainnya yang pernah diteliti (Kim, et al., 2011). BSF telah diteliti dapat mendegradasi sampah organik dengan memanfaatkan larvanya yang akan mengekstrak energi dan nutrien dari sampah sayuran, sisa makanan, bangkai hewan, dan kotoran sebagai bahan makanannya (Popa dan Green, 2012). Selain itu 
menurut Diener (2010), Larva BSF mampu mendegradasi sampai dengan 80\% jumlah sampah organik yang diberikan.

\subsection{Kuantitas Kompos Cair}

Penurunan massa kompos padat yang telah dibahas sebelumnya terjadi karena berkurangnya kadar air pada sampah, dimana kadar air tersebut sebagian berubah menjadi kompos cair yang tertampung pada ember yang diletakkan diruang paling bawah reaktor. Hasil pengukuran volume kompos cair selama 30 hari ditunjukan pada gambar 5.

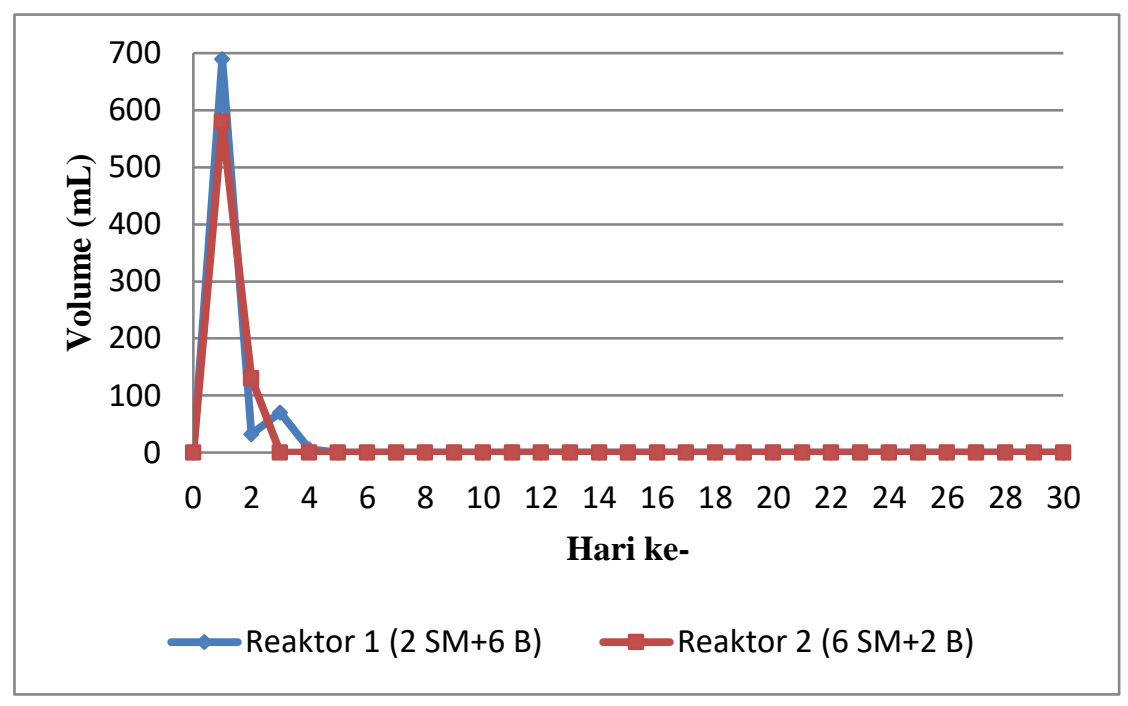

Gambar 5 Perubahan nilai kompos cair selama 30 hari proses pengomposan

Berdasarkan hasil pengamatan, reaktor satu menghasilkan kompos cair hanya hari ke-1 hingga hari ke-4 sebanyak $798 \mathrm{~mL}$ dan reaktor dua menghasilkan kompos cair hanya pada hari ke-1 dan hari ke-2 sebanyak $710 \mathrm{~mL}$. Pada hari pertama kompos cair reaktor satu berwarna merah dan encer sedangkan hari ke-4 berwarna coklat tua dan lebih pekat. Keluarnya kompos cair pada reaktor 2 hanya berlangsung dua hari. Pada hari pertama kompos cair reaktor dua berwarna coklat muda dan lebih pekat sedangkan hari ke-2 berwarna masih sama dengan hari ke-1 yaitu coklat muda dan lebih pekat. Warna merah pada kompos cair direaktor 1 dikarenakan feedstock yang digunakan lebih banyak buah-buahan yang telah dicampur dengan nasi kering dan bersih. Sedangkan pada reaktor dua terlihat bahwa kompos cair lebih mengandung minyak dan pekat karena sampah sisa makanan yang digunakan berupa nasi yang tercampur mie dan kuah. Kuantitas kompos cair yang dihasilkan lebih rendah bila dibandingkan dengan hasil pengomposan limbah buah dengan campuran sayur yaitu mencapai $1.984 \mathrm{~mL}$ (Hanifah, 2018). 


\section{KESIMPULAN}

Berdasarkan hasil penelitian dan analisis data menunjukkan bahwa Suhu akhir yang diperoleh pada reaktor $128^{\circ} \mathrm{C}$ dan $27^{\circ} \mathrm{C}$ pada reaktor 2. Pada reaktor 1 dan 2 suhu kompos sudah mencapai suhu tanah.selanjutnya Untuk nilai $\mathrm{pH}$ kedua reaktor pada penelitian ini 7-7,4, hal ini telah memenuhi kriteria pH pada SNI 19-7030-2004 tentang Spesifikasi Kompos dari Sampah Organik Domestik Massa kompos padat yang dihasilkan pada reaktor satu sebesar 1,800 kg dan $0,740 \mathrm{~kg}$ untuk reaktor dua. Penurunan massa reaktor dua lebih drastis dibandingkan dengan reaktor satu hal tersebut dapat dipengaruhi oleh kuantitas kompos cair dan produksi maggot. Sedangkan kompos cair yang dihasilkan sebanyak $798 \mathrm{ml}$ pada reaktor 1 dan 710 pada reaktor 2.

\section{DAFTAR PUSTAKA}

Anindita, F. (2012). Pengomposan dengan Menggunakan Metode In Vessel System Untuk Sampah UPS Kota Depok. Skripsi. Teknik Lingkungan, Universitas Indonesia.

Dewilda dan Listya. (2017). Pengaruh Komposisi Bahan Baku Kompos (Sampah Organik Pasar, Ampas Tahu, dan Rumen Sapi) terhadap Kualitas dan Kuantitas Kompos. Jurnal Teknik Lingkungan UNAND, 14 (1) : 52-61.

Diener, S., Zurbrügg,C., Gutiérrez, F.R., Nguyen, D.H., Morel, A., Koottatep, T., and Tockner, K. (2011). Black Soldier Fly Larvae for Organic Waste Treatment-Prospects and Constraints. Proceedings of the WasteSafe 2011-2 ${ }^{\text {nd }}$ International Conference on Solid Waste Management in the Developing Countries, 52: 1-8.

Djuarnani, N., Kristiani., dan Budi, S. (2005). Cara Cepat Membuat Kompos. Jakarta : Agromedia Pustaka.

Hadisuwito, S. (2007). Membuat Pupuk Kompos Cair. Jakarta: AgroMedia Pustaka.

Hanifah, N. P. (2018). Uji Kualitas - Kuantitas Hasil Pengomposan Reaktor Aerob Termodifikasi dari Kombinasi Sampah Sayur dan Sampah Buah. Tugas Akhi. Teknik Lingkungan, Universitas Islam Indonesia.

Iswadianto. (2018). Studi Timbulan, Komposisi dan Perencanaan Pengelolaan Sampah Pasar (Studi Kasus di Wilayah Pasar Kabupaten Sleman, Yogyakarta). Tugas Akhir. Teknik Lingkungan, Universitas Islam Indonesia.

Kim, W., Bae,S., Park, K., Lee,S., Choi, Y., Han, S., and Koh, Y(2011). Biochemical Characterization of Digestive Enzymes in the Black Soldier Fly, Hermetia illucens (Diptera: Stratiomyidae). Jurnal of Asia-Pasific Entomology, 14(1):11- 14. 
Liu, T., Awasthi, M.K., Chen, H., Duan, Y., Awasthi, S.K., and Zhang, Z. (2019). Performance of Black Soldier Fly Larvae (Diptera : Stratiomyide) for Manure Composting and Production of Cleaner Compost. Journal of Environmental Management, 251 (3): 1-10.

Popa, R and Green, T. (2012). Black Soldier Fly Applications . DipTerra LCC e-Book.

Rahardiyan B dan Murdeani, D. A. (2006). Sikap Masyarakat Terhadap Pemilahan Sampah Berbasis Pengumpulan Terjadwal. Jurnal Infrastruktur dan Lingkungan Binaan, 2 (2) : $18-26$.

Salim, T dan Sriharti. (2008). Pemanfaatan Ampas Daun Nilam sebagai Kompos. Prosiding Seminar Nasional Teknoin Bidang Teknik Kimia dan Tekstil, B78-B83.

Setyaningsih, E., Astuti, D.S., dan Astuti, R. 2017. Kompos daun solusi kreatif pengendali limbah. Bioeksperimen, 3(2):45-51.

SNI 19-7030-2004 tentang Spesifikasi Kompos dari Sampah Organik Domestik.

Yu, G., Cheng, P., Chen, Y., Li, Y., Yang, Z., Chen, Y., and Tomberlin, J. (2011). Inoculating Poultry Manure with Companion Bacteria Influences Growth and Development of Black Soldier Fly (Diptera: Stratiomyidae) Larvae. Environmental Entomology, 40(1):30-35. 